\title{
Pengaruh Fixed Asset Intensity, Karakter Eksekutif, dan Leverage terhadap Penghindaran Pajak
}

\author{
Pratiwi Cynthia Lukito $^{1}$, Rachmawati Meita Oktaviani ${ }^{2}$ \\ Universitas Stikubank Semarang, Indonesia \\ pratiwicynthia06@gmail.com, meitarachma@edu.unisbank.ac.id
}

*Corresponding Author

Diajukan : 20 Oktober 2021

Disetujui : : 11 Nopember 2021

Dipublikasi : : 1 Januari 2022

\begin{abstract}
Tax avoidance is based on agency theory, where this theory explains that the company is a form of contract between the owner of the company (principal) and the manager (agent) of the company who takes care of the use and control within the company. Study aims to examine whether the intensity of fixed asset, executive character, and leverage have an effect on tax avoidance. Tax avoidance is an activity to avoid paying taxes legally in accordance with the provisions of the legislation carried out by the company in order to be able to pay the minimum tax possible to the state treasury. Population in this study were manufacture companies listed in Indonesia Stock Exchange (IDX) during the period 2017 to 2020. The sampling technique used purposive sampling and obtained 54 companies, so that the total sample obtained for 4 years was 216 research samples. This study used quantitative method and the analysis by data panel regression. Tax avoidance proxy by cash effective tax rate (CETR) which is cash paid in cash for pay taxes. Partially shows that the intensity of fixed assets has no effect on tax avoidance, executive character has a significant positive effect on tax avoidance, and leverage has no effect on tax avoidance. While the results of this study indicate that the intensity of fixed assets, executive character, and leverage simultaneously have a significant effect on tax avoidance with the value of Prob (F-statistic) 0.000000. Result of Adjusted R-square shows of fixed Asset intensity, executive character, and leverage have a significant effect on tax avoidance is 0.3343 or $33.43 \%$.
\end{abstract}

Keywords: fixed Asset intensity; executive character; leverage; tax avoidance

\section{PENDAHULUAN}

Perpajakan merupakan salah satu bentuk iuran rakyat kepada negara yang bersifat wajib dan diatur oleh undang-undang negara tanpa mendapatkan imbalan secara langsung. Melalui perpajakan, pemerintah akan dapat menjalankan programnya dengan tujuan meningkatkan pertumbuhan ekonomi. Salah satu penerimaan pajak yang diperoleh negara salah satunya dipungut dari wajib pajak badan (perusahaan). Perusahaan berkembang dengan cepat, maka akan menghasilakan laba perusahaan yang cukup besar pula sehingga beban pajak perusahaan akan meningkat hal tersebut akan menjadi fokus pemerintah dalam memungut pajaknya. Sahrir (2021), menyebutkan besarnya pajak yang akan dibayarkan harus sesuai dengan laba yang didapatkan oleh perusahaan, sehingga hal tersebut akan menimbulkan praktik penghindaran pajak yang dilakukan oleh perusahaan.

Aprilia et al., (2020), menyatakan penghindaran pajak adalah salah satu cara untuk meminimalkan pembayaran pajak secara legal dan tidak melanggar peraturan perundangundangan. Secara hukum penghindaran pajak tidak dilarang namun tidak diinginkan oleh pemerintah. Hal tersebut membuat timbul adanya konflik kepentingan antara agen (manajemen) dengan principal yang timbul ketika setiap pihak ingin mencapai tingkat kemakmuran yang 
dikehendakinya, teori tersebut terdapat pada praktek penghindaran pajak dalam perspektif teori agensi.

Fenomena yang mencuat pada tahun 2019 merupakan salah satu perusahaan yang bergerak di sektor manufaktur yaitu PT Bentoel International Investama Tbk (RMBA). Dikutip dari website Kontan.co.id. Jika PT Bentoel International Investama Tbk (RMBA) diduga melakukan penghindaran pajak, Indonesia merugi sebesar US\$ 14 Juta. Berita tersebut menyebutkan bahwa Lembaga Tax Justice Network telah melaporkan perusahaan tembakau milik British American Tobacco (BAT) melakukan penghindaran pajak di Indonesia melalui PT Bentoel Internasional Investama. Penghindaran pajak yang dilakukan oleh PT Bentoel International Investama Tbk (RMBA) melalui pengambilan utang dari perusahaan afiliasi di Belanda yaitu Rothmans Far East BV untuk pembiayaan ulang utang bank serta membayar mesin dan peralatan. Hal tersebut akan mengakibatkan pajak yang dibayarkan lebih sedikit, sebab utang yang diambil akan menimbulkan beban bunga perusahaan, sehingga berdampak pada negara yang menderita kerugian sebesar US\$ 14 juta per tahun.

Akibat dari fenomena di atas membuktikan bahwa perusahaan-perusahaan yang ada di Indonesia berusaha untuk meminimalisir pembayaran pajak tanpa melanggar peraturan perundang-undangan. Salah satunya dengan memperbesar utang yang dilakukan perusahaan. Ratnasari dan Nuswantara (2020), menyebutkan timbulnya utang maka timbul pula beban bunga hal tersebut dapat memperkecil pembayaran pajak yang akan di setorkan perusahaan ke kas negara.

Fixed asset intensity merupakan rasio yang menandakan intensitas kepemilikan aset tetap suatu perusahaan dibandingkan dengan total aset perusahaan Ningsih et al., (2020). Perusahaan menggambarkan banyaknya investasi dalam bentuk modal terhadap aset tetap perusahaan. Pemilihan investasi dalam bentuk aset tetap yang berkaitan dengan perpajakan adalah dalam hal beban depresiasi (penyusutan). Beban penyusutan yang berkaitan pada kepemilikan aset tetap akan berpengaruh terhadap pajak perusahaan, hal ini dikarenakan beban penyusutan akan bertindak sebagai pengurang pajak. Sehingga semakin besar jumlah kepemilikan aset tetap yang dimiliki oleh perusahaan akan semakin besar pula beban penyusutan sehingga mengakibatkan jumlah beban pajak akan semakin kecil. Penelitian terdahulu menyatakan bahwa fixed asset intensity berpengaruh signifikan positif terhadap penghindaran pajak Dharma dan Noviari (2017); Noviyani dan Muid (2019); serta Ramadhan dan Kurnia (2021). Sedangkan penelitian lain menyatakan sebaliknya, bahwa fixed asset intensity tidak berpengaruh terhadap penghindaran pajak Oktaviani et al., (2021); Aprilia et al., (2020); Ningsih et al., (2020); Prapitasari (2019).

Karakter eksekutif terdiri dari dua karakter yang dimiliki oleh pemimpin perusahaan (eksekutif), yaitu risk taker dan risk averse. Eksekutif yang memiliki karakteristik sebagai risk taker akan menggunakan kemampuannya untuk memaksimalkan laba perusahaan dengan mengambil keputusan-keputusan yang berisiko. Sedangkan eksekutif yang memiliki karakteristik sebagai risk averse akan cenderung menghindari risiko sehingga cenderung kurang berani dalam melakukan penghindaran pajak. Sehingga dalam penelitian ini menyatakan bahwa karakter eksekutif bepengaruh positif terhadap penghindaran pajak. Hal tersebut sejalan dengan penelitian yang dilakukan oleh Pratomo dan Triswidyaria (2021); Aprilia et al., (2020); Oktamawati (2017), sedangkan penelitian lain menyebutkan karakter eksekutif tidak berpengaruh terhadap penghindaran pajak Fitria (2018); Windyasari (2019); serta Tj Ekaputra et al., (2020).

Leverage merupakan rasio yang menggambarkan tingkat risiko perusahaan yang diukur dengan membandingkan total utang dengan total aset yang dimiliki oleh perusahaan. Perusahaan dimungkinkan menggunakan utang untuk memenuhi kebutuhan operasional dan investasi perusahaan. Maka dalam penelitian ini rasio yang digunakan adalah DAR. DAR rasio ini dapat mengukur seberapa besar jumlah aset perusahaan yang dibiayai menggunakan total utang (liabilitas). Hal ini didukung dengan penelitian yang dilakukan Oktaviani et al., (2021); Putri et al., (2021); Tristianto dan Oktaviani (2016); serta Ratnasari dan Nuswantara (2020), menyatakan leverage memiliki pengaruh signifikan positif terhadap penghindaran pajak. Namun hal tersebut tidak selaras dengan penelitian yang dilakukan oleh Aprilia et al., (2020); S Anindyka et al., (2018); serta Byannur dan Nursiam (2021), menyatakan leverage tidak memiliki pengaruh terhadap penghindaran pajak. 
Berdasarkan penelitian terdahulu masih terdapat ketidakkonsistenan. Variabel fixed asset intensity, karakter eksekutif, dan leverage masih dapat di uji kembali. Penghindaran pajak di Indonesia masih cukup tinggi khususnya untuk wajib pajak badan (perusahaan). Perbedaan dalam penelitian ini adalah menggunakan rumus EBIT untuk proxy variabel karakter eksekutif. Penelitian sebelumnya menggunakan proxy EBITDA untuk mengukur variabel karakter eksekutif. Proxy EBITDA melihat laba bersih setelah dikurangi pajak dan depresiasi serta amortisasi. Selain itu, metode analisa data yang digunakan dalam penelitian ini berbasis eviews 10 dengan menggunakan data panel.

\section{Teori Agensi (Agency Theory)}

\section{STUDI LITERATUR}

Teori agensi menjelaskan bahwa perusahaan merupakan bentuk kontrak antara pemilik perusahaan dengan manajer perusahaan yang mengurus penggunaan dan pengendalian didalam perusahaan. Safii et al., (2019), menjelaskan bahwa yang dimaksud dalam kontrak tersebut adalah pemilik perusahaan (principal) menyediakan fasilitas dan dana untuk kebutuhan operasi perusaahan, sedangkan manajer (agent) sebagai pemimpin operasional perusahaan yang mempunyai tanggung jawab dalam mengelola perusahaan sesuai kontrak yang diamanahkan oleh pemilik perusahaan.

\section{Fixed Asset Intensity}

Fixed asset intensity perusahaan menggambarkan banyaknya investasi perusahaan yang di bebankan terhadap aset tetap. Ningsih et al., (2020), menjelaskan fixed asset intensity perusahaan yang besar akan mengakibatkan beban penyusutan atas aset tetap yang besar pula, sehingga fixed asset intensity berpotensi menekan beban pajak perusahaan. Oleh karena itu, fixed asset intensity yang tinggi dalam konflik agensi akan dimanfaatkan oleh manajer untuk menghindari beban pajak dengan memperbesar investasi dalam aset tetap sehingga dapat memaksimalkan laba perusahaan dan tercapainya kepuasan kinerja manajer sesuai yang diinginkan. Aprilia et al., (2020), menyatakan bahwa, dengan memperbesar aset tetap akan menimbulkan beban penyusutan dalam perusahaan. Semakin besar jumlah kepemilikan aset tetap yang dimiliki oleh perusahaan akan semakin besar pula beban penyusutan, hal tersebut mengakibatkan jumlah beban pajak akan semakin kecil. Maka dari itu, praktik penghindaran pajak akan semakin agresif. Penelitian yang dilakukan oleh Ramadhan dan Kurnia (2021); Noviyani dan Muid (2019); serta Dharma dan Noviari (2017), menyatakan semakin besar Fixed asset intensity suatu perusahaan akan meningkatkan praktik penghindaran pajak. Berdasarkan uraian di atas, maka hipotesis pertama dari penelitian ini adalah:

\section{$\mathrm{H}_{1}=$ Fixed asset intensity berpengaruh positif terhadap penghindaran pajak}

\section{Karakter Eksekutif}

Karakter eksekutif harus melaksanakan kewajibannya sebagai pemimpin perusahaan, bahwa eksekutif memiliki dua karakter yaitu risk taker dan risk averse. Teori agensi menjelaskan jika atasan memberikan wewenang kepada bawahan untuk melaksanakan wewenang atau tugas untuk membuat keputusan, maka kebijakan dan pengambilan keputusan perusahaan dibuat oleh pimpinan perusahaan. Tj Ekaputra et al., (2020), menjelaskan eksekutif yang memiliki karakteristik sebagai risk taker akan menggunakan kemampuannya untuk memaksimalkan laba didalam perusahaan dengan mengambil keputusan-keputusan yang berisiko. Sedangkan eksekutif yang memiliki karakteristik sebagai risk averse akan cenderung menghindari risiko sehingga cenderung kurang berani dalam melakukan penghindaran pajak. Sehingga untuk mengetahui karakter eksekutif maka akan menggunakan risiko perusahaan (corporate risk) yang dimiliki perusahaan. Penelitian yang dilakukan oleh Pratomo dan Triswidyaria (2021); Aprilia et al., (2020); serta Oktamawati (2017), menyatakan semakin tinggi eksekutif memiliki karakteristik risk taker maka semakin tinggi penghindaran pajaknya. Berdasarkan uraian diatas, maka hipotesis kedua dari penelitian ini adalah:

\section{$\mathbf{H}_{2}=$ Karakter eksekutif berpengaruh positif terhadap penghindaran pajak}




\section{Leverage}

Leverage merupakan suatu ukuran seberapa besar aset yang dimiliki perusahaan yang dibiayai oleh hutang. Menurut Putri et al., (2021) menyatakan bahwa, akibat dari perusahaan yang memiliki tingkat hutang yang tinggi ialah timbul beban bunga yang menjadi pengurang beban pajak perusahaan. Hal tersebut didukung oleh teori keagenan, dimana teori tersebut menyatakan perusahaan dengan debt ratio memiliki tingkat penghindaran pajak yang tinggi. Dikarenakan hutang perusahaan meningkatkan beban bunga, sehingga dapat mengurangi keuntungan perusahaan. Dengan keuntungan perusahaan yang menurun, maka pajak perusahaan yang harus dibayarkan ke kas negara juga akan berkurang. Sebaliknya, perusahaan dengan tingkat hutang yang rendah akan memiliki tingkat penghindaran pajak yang rendah pula. Penelitian yang dilakukan oleh Tristianto dan Oktaviani (2016); Oktamawati (2017); Ratnasari dan Nuswantara (2020); Putri et al., (2021); serta Oktaviani et al., (2021), menyatakan bahwa semakin tinggi utang perusahaan, maka semakin tinggi pula pajak perusahaan yang mengakibatkan penghindaran pajak akan semakin agresif. Berdasarkan uraian diatas, maka hipotesis ketiga dari penelitian ini adalah:

\section{$\mathrm{H}_{3}=$ Leverage berpengaruh positif terhadap penghindaran pajak}

\section{METODE}

Penelitian ini dilakukan dengan menggunakan pendekatan kuantitatif. Penelitian dengan menggunakan pendekatan kuantitatif adalah pengumpulan data menggunakan sampel dan kriteria untuk menjelaskan fenomena tertentu. Tujuan dilakukannya penelitian ini adalah untuk mengetahui pengaruh dari fixed asset intensity, karakter eksekutif, dan leverage terhadap penghindaran pajak.

Populasi yang digunakan dalam penelitian ini adalah perusahaan manufaktur yang terdaftar di Bursa Efek Indonesia (BEI) periode 2017-2020. Teknik pemilihan sampel menggunakan metode purposive sampling dengan kriteria dengan sebagai berikut:

Tabel 1. Hasil Pemilihan Sampel

\begin{tabular}{llc}
\hline No. & \multicolumn{1}{c}{ Kriteria } & Jumlah \\
\hline 1. & $\begin{array}{l}\text { Perusahaan manufaktur yang terdaftar selama periode 2017-2020 } \\
\text { 2. }\end{array}$ & $\begin{array}{l}\text { Perusahaan manufaktur yang menggunakan mata uang dollar } \\
\text { dalam pelaporannya }\end{array}$ \\
3. & $\begin{array}{l}\text { Perusahaan manufaktur yang tidak menerbitkan informasi } \\
\text { lengkap mengenai data yang berkaitan dengan variabel penelitian } \\
\text { selama periode 2017-2020 }\end{array}$ & \\
4. & $\begin{array}{l}\text { Perusahaan yang mengalami kerugian selama periode 2017-2020 } \\
\text { serta memiliki nilai CETR diatas 100\% } \\
\text { Jumlah Sampel Akhir } \\
\text { Total Sampel (4 Tahun) }\end{array}$ & $(57)$ \\
& & 54 \\
\hline
\end{tabular}

Proxy yang digunakan dalam perhitungan tax avoidance sebagai variabel dependen (Y) pada penelitian ini adalah dengan menggunakan Cash Effective Tax Rate (CETR). Oktamawati (2020), menjelaskan bahwa, CETR dipilih untuk proxy tax avoidance karena merupakan kas yang dibayarkan secara tunai untuk membayar pajak, sehingga diharapkan mampu mengidentifikasi keagresifan perencanaan pajak. Tingkat presentase CETR yang hampir mencapai tarif pajak penghasilan badan sebesar 25\% maka dapat menunjukkan jika rendahnya tingkat penghindaran pajak yang dilakukan perusahaan. Sehingga dapat diambil kesimpulan apabila tingkat presentase CETR semakin rendah maka hal tersebut membuktikan bahwa tingginya potensi praktik penghindaran pajak yang dilakukan oleh perusahaan Prapitasari dan Safrida (2019). Perhitungan CETR yaitu sebagai berikut:

$$
\mathrm{CETR}=\frac{\text { Pembayaran Pajak }}{\text { Laba Sebelum Pajak }}
$$


Selanjutnya, untuk variabel fixed asset intensity sebagai variabel independen pertama $\left(\mathrm{X}_{1}\right)$ pada penelitian ini bahwa fixed asset intensity mencerminkan presentasi atau proporsi dari aset tetap yang dimiliki perusahaan dengan cara dibandingkan dengan total aset yang dimilikinya Riantami dan Triyanto (2018).

$$
\text { Fixed Asset Intensity }=\frac{\text { Total Aset Tetap }}{\text { Total Aset }}
$$

Karakter eksekutif sebagai variabel independen kedua $\left(X_{2}\right)$, Windyasari et al., (2019), menjelaskan karakter eksekutif dapat terlihat dari besar atau kecilnya corporate risk. Corporate risk atau dapat disebut dengan risiko perusahaan merupakan deviasi standar earning perusahaan yang dapat bernilai lebih dari yang direncanakan ataupun kurang dari yang direncanakan. Semakin tinggi corporate risk maka eksekutif memiliki karakter sebagai risk taker yang dimana upaya melakukan tax avoidance pun semakin tinggi, sedangkan rendahnya corporate risk maka eksekutif memiliki karakter sebagai risk averse dimana upaya melakukan tax avoidance cenderung dihindari.

$$
\text { Risiko Perusahaan }=\frac{E B I T}{\text { Total Aset }}
$$

Leverage sebagai variabel independen ketiga $\left(\mathrm{X}_{3}\right)$ dalam penelitian ini menggunakan proxy Debt Asset Ratio (DAR). Aprilia et al., (2020), menjelaskan bahwa, DAR lebih efektif digunakan untuk mengukur variabel leverage karena dapat mengukur seberapa besar jumlah aset perusahaan yang dibiyai menggunakan total utang (liabilitas).

$$
\mathrm{DAR}=\frac{\text { Total Liabilitas }}{\text { Total Aset }}
$$

Tahap awal penganalisisan data menggunakan statistik deskriptif. Setelah itu dilakukan analisis data menggunakan data panel dengan. Rumus regresi data panel adalah sebagai berikut:

\section{Penghindaran pajak $=\alpha+\beta_{1 i t}$ fixed asset intensity $+\beta_{2 i t} k a r a k t e r$ eksekutif $+\beta_{3 i t}$ leverage $+\boldsymbol{e}_{i t}$}

Keterangan:

$\mathrm{Y} \quad=$ Penghindaran Pajak

$\alpha \quad=$ Konstanta

$\beta_{1} \beta_{2} \beta_{3}=$ Koefisien regresi masing-masing variable independen

$\mathrm{X}_{1 \mathrm{it}} \quad=$ Fixed Asset Intensity

$\mathrm{X}_{2 \mathrm{it}} \quad=$ Karakter Eksekutif

$\mathrm{X}_{3 \mathrm{it}}=$ Leverage

$e_{i t} \quad=$ Error term

HASIL

Hasil pengolahan data digambarkan secara umum menggunakan pendeskripsian data dengan statistik deskriptif. Pendeskripsian data dilakukan dengan nilai maximum, minimum, mean, dan standar deviasi pada tidap-tiap variabel. 
Tabel 2. Statistik Deskriptif

Descriptive Statistics

\begin{tabular}{|c|c|c|c|c|}
\hline & $\begin{array}{c}\text { Penghindaran } \\
\text { pajak }\end{array}$ & $\begin{array}{c}\text { Fixed aset } \\
\text { intensity }\end{array}$ & $\begin{array}{l}\text { Karakter } \\
\text { eksekutif }\end{array}$ & Leverage \\
\hline Mean & 0.275694 & 0.392361 & 0.124444 & 0.358426 \\
\hline Median & 0.250000 & 0.400000 & 0.095000 & 0.350000 \\
\hline Maximum & 0.870000 & 0.780000 & 0.730000 & 0.780000 \\
\hline Minimum & 0.000000 & 0.000000 & 0.010000 & 0.030000 \\
\hline Std. Dev. & 0.144588 & 0.191531 & 0.116586 & 0.171041 \\
\hline Skewness & 1.418239 & 0.012436 & 2.651580 & 0.310974 \\
\hline Kurtosis & 5.935417 & 2.359258 & 11.72680 & 2.402092 \\
\hline Jarque-Bera & 149.9605 & 3.700520 & 938.5242 & 6.698812 \\
\hline Probability & 0.000000 & 0.157196 & 0.000000 & 0.035105 \\
\hline Sum & 59.55000 & 84.75000 & 26.88000 & 77.42000 \\
\hline Sum Sq. Dev. & 4.494696 & 7.887096 & 2.922333 & 6.289865 \\
\hline Observations & 216 & 216 & 216 & 216 \\
\hline Cross Sections & 54 & 54 & 54 & 54 \\
\hline
\end{tabular}

Tabel 2. Menunjukkan bahwa jumlah data observasi sebanyak 216 yang terdiri dari 54 sampel pertahun. Variabel dependen dalam penelitian ini yaitu penghindaran pajak dengan dengan nilai CETR objek penelitian sangat bervariasi dengan nilai minimum sebesar 0.000000 dari perusahaan dengan kode SMBR dan nilai maksimum sebesar 0.870000 dari perusahaan dengan kode MLIA. Rata-rata pada variabel penghindaran pajak sebesar 0.275694 dan nilai standar deviasi sebesar 0.144588. Hasil tersebut menunjukan bahwa nilai standar deviasi lebih kecil dari nilai rata-rata sehingga nilai tersebut diartikan berkelompok.

Variabel fixed asset intensity memiliki nilai minimum sebesar 0.000000 dari perusahaan dengan kode KDSI dan nilai maksimum sebesar 0.780000 yang dimiliki oleh perusahaan MLIA. Rata-rata variabel fixed asset intensity sebesar 0.392361 dan nilai standar deviasi 0.191531 . Hasil tersebut menunjukan bahwa nilai standar deviasi lebih kecil dari nilai rata-rata sehingga nilai tersebut diartikan berkelompok.

Nilai maksimum pada variabel karakter eksekutif yang dimiliki oleh perusahaan yang memiliki kode LPIN sebesar 0.730000 dan nilai minimum sebesar 0.010000 yang terdapat pada perusahaan yang memiliki kode KBLM. Untuk rata-rata nilai variabel karakter eksekutif sebesar 0.124444 dan nilai standar deviasi sebesar 0.116586. Hasil tersebut menunjukan bahwa nilai standar deviasi lebih kecil dari nilai rata-rata sehingga nilai tersebut diartikan berkelompok.

Sedangkan variabel leverage memiliki nilai maksimum sebesar 0.780000 yang terdapat pada perusahaan yang memiliki kode INAI dan memiliki nilai minimum sebesar 0.030000 yang dimiliki oleh perusahaan yang memiliki kode IGAR. Untuk nilai rata-rata yang dimiliki oleh variabel leverage sebesar 0.358426 dan nilai standar deviasinya sebesar 0.171041 . Hasil tersebut menunjukan bahwa nilai standar deviasi lebih kecil dari nilai rata-rata sehingga nilai tersebut diartikan berkelompok.

Tabel 3. Hasil Uji Chow

\begin{tabular}{lrrr}
\hline Effects Test & Statistic & d.f. & Prob. \\
\hline Cross-section F & 2.893669 & $(53,159)$ & 0.0000 \\
Cross-section Chi-square & 145.857541 & 53 & 0.0000 \\
\hline \multicolumn{1}{c}{ Sumber }
\end{tabular}

Sumber: data dari eviews 10 (Data Diolah Peneliti, 2021) 
Tabel 3. Hasil uji Chow dari tabel diatas menunjukkan nilai probabilitas F-statistik $0.0000<0.05$. Nilai F-statistik $145.857541>$ dari F-tabel 2.893669. Nilai tersebut menghasilkan keputusan bahwa $\mathrm{H}_{0}$ ditolak dan $\mathrm{H}_{1}$ diterima. Pada penelitian ini model fixed effect model merupakan metode yang tepat dalam meregresi data panel dalam penelitian ini. Hasil uji chow memberikan keputusan bahwa fixed effect model lebih baik dan akan dilanjutkan dengan uji hausman.

Tabel 4. Hasil Uji Hausman

\begin{tabular}{cccc}
\hline Test Summary & Chi-Sq. Statistic & Chi-Sq. d.f. & Prob. \\
Cross-section random & $\mathbf{1 3 . 5 7 3 1 2 2}$ & $\mathbf{3}$ & $\mathbf{0 . 0 0 3 5}$ \\
\hline \multicolumn{2}{c}{ Sumber: data dari eviews 10 (Data Diolah Peneliti, 2021) }
\end{tabular}

Tabel 4. Uji hausman menghasilkan nilai probabilitas sebesar $0.0035<0.05$ sehingga uji fixed effect model dapat digunakan dalam penelitian ini. Serta, nilai prob Fstatistic pada random effect model sebesar 0.043335 dan fixed effect model sebesar 0.000000. Hasil tersebut dapat disimpulkan bahwa peneliti menggunakan metode penelitian fixed effect model. Sebab Prob F-statistic pada metode fixed effect model lebih kecil daripada nilai prob f-statistic pada metode random effect model.

Tabel 5. Output Regresi Pada Data Panel Fixed Effect Model Dependen Variabel: Penghindaran Pajak

Dependent Variable: $\mathrm{Y}$

Method: Panel Least Squares

Date: 10/12/21 Time: 23:04

Sample: 20172020

Periods included: 4

Cross-sections included: 54

Total panel (balanced) observations: 216

\begin{tabular}{crrrr}
\hline Variable & Coefficient & Std. Error & t-Statistic & Prob. \\
\hline C & 0.362865 & 0.079159 & 4.584009 & 0.0000 \\
Fixed aset intensity & 0.123066 & 0.124525 & 0.988284 & 0.3245 \\
Karakter eksekutif & 0.736370 & 0.144514 & 5.095500 & 0.0000 \\
Leverage & -0.122255 & 0.152558 & -0.801367 & 0.4241 \\
\hline
\end{tabular}

Effects Specification

Cross-section fixed (dummy variables)

\begin{tabular}{cccr}
\hline R-squared & 0.507738 & Mean dependent var & 0.275694 \\
Adjusted R-squared & $\mathbf{0 . 3 3 4 3 6 3}$ & S.D. dependent var & 0.144588 \\
S.E. of regression & 0.117964 & Akaike info criterion & -1.215470 \\
Sum squared resid & 2.212568 & Schwarz criterion & -0.324771 \\
Log likelihood & 188.2707 & Hannan-Quinn criter. & -0.855625 \\
F-statistic & 2.928549 & Durbin-Watson stat & 2.533476 \\
Prob(F-statistic) & $\mathbf{0 . 0 0 0 0 0 0}$ & & \\
\hline \multicolumn{4}{c}{ Sumber: data dari eviews 10 (Data Diolah Peneliti, 2021) }
\end{tabular}

Tabel 5. Menunjukkan bahwa hasil data uji fixed effect model di atas menyatakan bahwa rata-rata variabel penghindaran pajak dari 216 sampel adalah sebesar 36,28\%. Penghindaran pajak dipengaruhi oleh fixed asset intensity, karakter eksekutif, dan leverage. Hasil tersebut menunjukkan adanya pengaruh dari variabel independen. 
Pengaruh dari variabel independen dijelaskan peningkatan fixed asset intensity sebesar $1 \%$ maka, penghindaran pajak mengalami peningkatan agresif sebesar $12,3 \%$. Sehingga variabel fixed asset intensity memiliki nilai koefisien regresi sebesar 0.123066 dan nilai prob sebesar 0.3245 yang berarti $0.3245>0.05$. Berdasarkan kriteria tersebut maka hipotesis fixed asset intensity tidak berpengaruh terhadap penghindaran pajak, sehingga $\mathbf{H 1}$ ditolak.

Apabila ada peningkatan pada variabel karakter eksekutif sebesar 1\% maka, penghindaran pajak mengalami peningkatan agresif sebesar $73,6 \%$. Sehingga variabel karakter eksekutif nilai koefisien regresi sebesar 0.736370 dan nilai prob sebesar 0.0000 yang berarti $0.0000<0.05$. Berdasarkan kriteria tersebut maka hipotesis karakter eksekutif berpengaruh positif terhadap penghindaran pajak, sehingga $\mathbf{H 2}$ diterima.

Sedangkan apabila hasil variabel leverage mengalami kenaikan sebesar $1 \%$ maka, penghindaran pajak turun sebesar $-12,2 \%$. Sehingga variabel leverage nilai koefisien regresi sebesar-0.122255 dan nilai prob sebesar 0.4241 yang berarti $0.4241>0.05$. Berdasarkan kriteria tersebut maka hipotesis leverage tidak berpengaruh terhadap penghindaran pajak, sehingga $\mathbf{H 3}$ ditolak.

Tabel 5. Nilai Adjusted R-square pada tabel uji fixed effect model sebesar 0.334363 dan nilai Prob F-statistic sebesar 0.000000. Nilai Adjusted R-square sebesar 0.334363 menunjukkan bahwa $33.43 \%$ perubahan penghindaran pajak dapat dijelaskan oleh fixed asset intensity, karakter eksekutif, dan leverage yang merupakan variabel bebas pada penelitian ini. Dari $33.43 \%$ sisa $66.57 \%$ perubahan penghindaran pajak dijelaskan oleh variabel diluar penelitian ini.

Tabel 5. Memperlihatkan bahwa uji fixed effect model terdapat nilai Prob F-statistic sebesar 0.000000 lebih kecil dari significant level $0.05(5 \%)$ yang menunjukkan bahwa variabel bebas ini dapat mempengaruhi penghindaran pajak secara signifikan. Pengujian ini dilakukan dengan menggunakan variabel independen fixed asset intensity, karakter eksekutif, dan leverage secara simultan terhadap penghindaran pajak. Berdasarkan tabel 5 , dapat dilihat bahwa nilai prob (Fstatistic) yaitu sebesar $\mathbf{0 . 0 0 0 0 0 0}$ atau lebih kecil dari significant level $0.05(5 \%)$ maka hasilnya $\mathrm{H}_{0}$ di tolak, sehingga variabel independen dalam penelitian ini yaitu fixed asset intensity, karakter eksekutif, dan leverage berpengaruh secara simultan terhadap penghindaran pajak pada perusahaan manufaktur periode 2017-2020.

\section{PEMBAHASAN}

\section{Pengaruh Fixed Asset Intensity terhadap Penghindaran Pajak}

Hasil uji regresi data panel mengemukakan bahwa fixed asset intensity tidak berpengaruh terhadap penghindaran pajak. Hasil penelitian ini menolak hipotesis pertama $\left(\mathrm{H}_{1}\right)$ yang menyatakan bahwa fixed asset intensity berpengaruh positif signifikan terhadap penghindaran pajak. Perusahaan yang memiliki kepemilikan aset tetap bukan hanya untuk mengatasi penghindaran pajak melainkan untuk mendukung jalannya operasional dalam sebuah perusahaan. Hasil penelitian ini sejalan dengan hasil penelitian yang dilakukan oleh Oktaviani et al., (2021); Aprilia et al., (2020); Ningsih et al., (2020); Prapitasari (2019); serta Riantami dan Triyanto (2018), menyatakan bahwa, fixed asset intensity tidak berpengaruh terhadap penghindaran pajak.

\section{Pengaruh Karakter Eksekutif terhadap Penghindaran Pajak}

Hasil uji regresi data panel mengemukakan bahwa karakter eksekutif berpengaruh terhadap penghindaran pajak. Hasil penelitian ini menerima hipotesis kedua $\left(\mathrm{H}_{2}\right)$ yang menyatakan bahwa karakter eksekutif berpengaruh positif signifikan terhadap penghindaran pajak. Semakin tinggi risiko perusahaan (corporate risk) yang merupakan proksi dari karakter eksekutif menjelaskan bahwa karakter eksekutif yang bersifat risk taker akan lebih berani untuk memilih melakukan penghindaran pajak. Hasil penelitian ini sejalan dengan penelitian yang dilakukan oleh Pratomo dan Triswidyaria (2021); Aprilia et al., (2020); Oktamawati (2017) menyatakan bahwa karakter eksekutif berpengaruh positif signifikan terhadap penghindaran pajak. 


\section{Pengaruh Leverage terhadap Penghindaran Pajak}

Hasil uji regresi data panel mengemukakan bahwa leverage tidak berpengaruh terhadap penghindaran pajak. Hasil penelitian ini menolak hipotesis ketiga $\left(\mathrm{H}_{3}\right)$ yang menyatakan bahwa leverage berpengaruh positif signifikan terhadap penghindaran pajak. Perusahaan pada industri manufaktur baik perusahaan yang memiliki nilai leverage tinggi ataupun rendah lebih banyak tidak melakukan praktik penghindaran pajak, karena pendanaan melalui utang dipilih murni untuk mencari keuntungan atau mendukung operasional perusahaan bukan untuk menghindari pajak. Hasil penelitian ini sejalan dengan penelitian yang dilakukan oleh S Anindyka (2018); Byannur dan Nursiam (2021); serta Aprilia et al., (2020), menyatakan bahwa leverage tidak berpengaruh terhadap penghindaran pajak.

\section{KESIMPULAN}

Kesimpulan yang didapatkan berdasarkan pada hasil penelitian adalah bahwa fixed asset intensity tidak berpengaruh terhadap penghindaran pajak. Sebab, kepemilikan aset tetap bukan hanya untuk mengatasi penghindaran pajak melainkan untuk mendukung jalannya operasional dalam sebuah perusahaan. Karakter eksekutif berpengaruh positif signifikan terhadap penghindaran pajak, sebab semakin tinggi risiko perusahaan (corporate risk) yang merupakan proksi dari karakter eksekutif menjelaskan bahwa karakter eksekutif yang bersifat risk taker akan lebih berani untuk memilih melakukan penghindaran pajak. Sementara leverage tidak berpengaruh signifikan terhadap penghindaran pajak. Sebab, tinggi rendahnya nilai leverage tidak berpengaruh dalam melakukan praktik penghindaran pajak, karena pendanaan melalui utang dipilih murni untuk mencari keuntungan atau mendukung operasional perusahaan bukan untuk menghindari pajak yang dibayarkan oleh perusahaan. Serta fixed asset intensity, karakter eksekutif, dan leverage secara simultan berpengaruh signifikan terhadap penghindaran pajak dengan nilai Prob (F-statistik) sebesar 0.000000. Penelitian ini memiliki keterbatasan dimana dari ketiga variabel independen pada penelitian ini hanya mampu menjelaskan pengaruhnya terhadap penghindaran pajak sebesar 33,43\% diperoleh dari nilai Adjusted $R$-Squared sebesar 0,334363.

\section{REFERENSI}

Aprilia, V., Majidah, \& Asalam, A. G. (2020). Pengaruh intensitas aset tetap, karakter eksekutif, koneksi politik dan leverage terhadap tax avoidance (Studi pada Perusahaan Makanan dan Minuman yang Terdaftar di Bursa Efek Indonesia Tahun 2014 - 2018). Jurnal Ilmiah Akuntansi dan Finansial Indonesia, Volume 3, No. 2, 15-26.

Byannur, L., \& Nursiam. (2021). Pengaruh profitabilitas, leverage, sales growth, ukuran perusahaan, dan umur perusahaan terhadap tax avoidance. E-Prosiding Seminar Nasional Manajemen dan Akuntansi STIE Semarang (SENMAS), 1-13.

Dharma, N. B., \& Noviari, N. (2017). Pengaruh corporate social responsibility dan capital intensity terhadap tax avoidance. E-Jurnal Akuntansi Universitas Udayana, Vol.18.1. Januari (2017): 529-556.

Fitria, G. N. (2018). Pengaruh kepemilikan institusional, komisaris independen, karakter eksekutif dan size terhadap tax avoidance. Profita: Komunikasi Ilmiah Akuntansi dan Perpajakan, Vol. 11 No. 3, 438-451.

Ningsih, A. N., Irawati, W., Barli, H., \& Hidayat, A. (2020). Analisis karakteristik perusahaan, intensitas aset tetap dan konservatisme akuntansi terhadap tax avoidance. Systems UNPAM (Universitas Pamulang), Vol. 1, No. 2, 245-256.

Noviyani, E., \& Muid, D. (2019). Pengaruh return on assets, leverage, ukuran perusahaan, intensitas aset tetap dan kepemilikan institusional terhadap penghindaran pajak. DIPONEGORO JOURNAL OF ACCOUNTING, Volume 8, Nomor 3, 1-11. http://ejournal-s1.undip.ac.id/index.php/accounting

Oktamawati, M. (2017). Pengaruh karakter eksekutif, komite audit, ukuran perusahaan, leverage, pertumbuhan penjualan, dan profitabilitas terhadap tax avoidance. Jurnal Akuntansi Bisnis, Vol. 15, No. 1, 23-40.

Oktaviani, R. M., Pratiwi, Y. E., Sunarto, \& Jannah, A. (2021). The effect of leverage, earning management, capital intensity, and inventory intensity on tax aggressiveness of 
manufacturing companies in Indonesia. Journal of Asian Finance, Economics and Business, Vol 8 No 7, 0501-0508.

Prapitasari, A., \& Safrida, L. (2019). The effect of profitability, leverage, firm size, political connection and fixed asset intensity on tax avoidance (empirical study on mining companies listed in indonesia stock exchange 2015-2017). Accounting Research Journal of Sutaatmadja (ACCRUALS), 247-258. https://doi.org/10.35310/accruals.v3i2.56.

Pratomo, D., Kurnia, \& Maulani, A. J. (2021). Pengaruh non-financial distress, koneksi politik, dan intensitas persediaan terhadap tax avoidance. Jurnal Akuntansi Aktual, 2580-1015.

Prima, B., \& Dewi, H. K. (2019, Mei Rabu). Tax Justice laporkan Bentoel lakukan penghindaran pajak, Indonesia rugi US\$ 14 juta. Retrieved from KONTON.CO.ID: https://nasional.kontan.co.id/news/tax-justice-laporkan-bentoel-lakukan-penghindaranpajak-indonesia-rugi-rp-14-juta

Putri, A. A., Azmi, Z., \& Arsa, J. (2021). Apakah sales growth, leverage dan capital intensity mempengaruhi tax avoidance? Jurnal Akuntansi \& Ekonomika, Vol.11 No.1, 1-11. DOI:10.37859/jae.v11i1.1534.

Ramadhan, F., \& Kurnia, S.AB., M.M. (2021). Pengaruh preferensi risiko eksekutif, intensitas aset tetap, dan transfer pricing terhadap tax avoidance. e-Proceeding of Management, 1093.

Ratnasari, D., \& Nuswantara, D. A. (2020). Pengaruh kepemilikan institusional dan leverage terhadap penghindaran pajak (tax avoidance). AKUNESA: Jurnal Akuntansi Unesa, Vol. 09 No. 01, 1-10. https://journal.unesa.ac.id/index.php/akunesa.

Riantami, V. L., \& Triyanto, D. N. (2018). Pengaruh proporsi komisaris independen, financial distress, intensitas aset tetap, dan pertumbuhan penjualan terhadap tax avoidance (Studi pada Perusahaan Manufaktur Sub Sektor Makanan dan Minuman yang Terdaftar di Bursa Efek Indonesia Periode 2013-2017. EDUTECH CONSULTANT BANDUNG Jurnal AKSARA PUBLIC, Volume 2 Nomor 4, 23-35.

S Anindyka, D., Pratomo, S.E.,T., M.Ak, D., \& Kurnia, S.AB.,M.M. (2018). Pengaruh leverage (dar), capital intensity dan inventory intensity terhadap tax avoidance (Studi Pada Perusahaan Makanan dan Minuan di Bursa Efek Indonesia (BEI) Tahun 2011-2015). $e$ Proceeding of Management, 713.

Tj Ekaputra, R. R., \& Nazar, M. R. (2020). Pengaruh karakter eksekutif, capital intensity, dan kepemilikan keluarga terhadap tax avoidanve (Studi empiris pada perusahaan makanan dan minuman yang terdaftar di bursa efek indonesia periode 2014-2018). Jurnal Ilmiah Akuntansi dan Finansial Indonesia, Volume 3, No.2, 27-36.

Tristianto, D., \& Oktaviani , R. M. (2016). Faktor-faktor yang mempengaruhi tax avoidance dengan leverage sebagai variabel mediasi. Dinamika Akuntansi, Keuangan dan Perbankan, Vol. 5 No.1, 65-81.

Sahrir, Sultan, \& Syamsuddin, S. (2021). Pengaruh koneksi politik, intensitas aset tetap, komisaris independen, profitabilitas dan leverage terhadap tax avoidance. Jurnal Penelitian Ekonomi Akuntansi (JENSI), Volume 5 Nomor 1, 14-30.

Windyasari, M. K., Harimurti, F., \& Suharno. (2019). Pengaruh strategi bisnis, karakter eksekutif, dan ukuran perusahaan terhadap tax avoidance. Jurnal Akuntansi dan Sistem Teknologi Informasi, Vol. 15 No. 1, 82-92. 